\title{
Possibilities of Using Social Networks as Tools for Integration of Czech Rural Areas - Survey 2021
}

\author{
Eva Kánská,' Michal Stočes, Jan Masner, Jan Jarolímek, Pavel Šimek, Jiří Vaněk \\ Department of Information Technology, Faculty of Economics and Management, Czech University of Life \\ Sciences Prague, Czech Republic
}

\begin{abstract}
This paper deals with the use of social networks in agricultural enterprises and focuses mainly on their role and share in increasing the competitiveness of agricultural enterprises in the market. Primary data were obtained from an extensive survey of the development of information and communication technologies in agricultural enterprises, which was conducted in the first quarter of 2021 throughout the Czech Republic ("Survey 2021"). The research was primarily focused on capturing current trends in the use of ICT with emphasis on selected key areas (broadband, social networks, communication tools, regional Internet portals, used hardware categories, used software, mobile communications, Internet of Things, data storage and security, social networks, etc.).

This survey builds on previous extensive surveys conducted by the Department of Information Technologies, Faculty of Electrical Engineering, CULS in Prague in several phases since 1999, with the last stage being conducted in 2017. Some surveys were conducted in cooperation with the Ministry of Agriculture of Czech Republic.

Compared to recent years, the survey includes new domains, such as the use of the Internet of Things in plant and animal production, data storage and security, the impact of the Covid-19 pandemic on the company's core operations, etc. The survey was prepared, conducted and administered by the Department of Information Technology, Faculty of Economics and Management, University of Life Sciences Prague.
\end{abstract}

\section{Keywords}

Social network, Facebook, agricultural activity, non-agricultural activity, business, marketing, online communication, rural area.

Kánská, E., Stočes, M., Masner, J., Jarolímek, J., Šimek, P. and Vaněk, J. (2021) "Possibilities of Using Social Networks as Tools for Integration of Czech Rural Areas - Survey 2021", AGRIS on-line Papers in Economics and Informatics, Vol. 13, No. 3, pp. 59-66. ISSN 1804-1930. DOI 10.7160/aol.2021.130306.

\section{Introduction}

Today, social networks are used by almost everyone and almost every day, and therefore it is a very effective marketing tool. This article links this new trend to the specific environment of rural areas.

The social network acts as a bridge providing active communication with a selected target group, with whom it is difficult to establish communication (Kánská et al., 2011). Social media has thus become an integral part of the marketing strategy of many companies around the world and in recent years has literally expanded into all industries. The funds devoted to this type of marketing activity are rising sharply, as are the number of companies involved in communication and promotion on social networks. The Internet has become a transmitter for the further rise and development of social networks aimed at different groups of users. Internet social media overcomes one of the biggest limitations - a connection to a certain place (place of business, residence, etc).

The Covid-19 pandemic has swept the world in recent months. The depth and duration of the economic crisis caused by the coronavirus pandemic will affect not only our way of life but also the future of many businesses. And this crisis has only helped people look for brands they can trust and that contribute to their safety. People want to be assured that "their" brands have the situation with their suppliers under control, are transparent and trustworthy. This is largely due to customers' 
efforts to avoid malls for fear of becoming infected with the virus. But the key lesson is that users know where to turn. In times of crisis, they look for what they know, whether a product or a service.

In the Czech Republic, social networks are still partly perceived as a tool for private interpersonal communication and not as a marketing tool. However, the number of companies using social networking as a source of information or to aid public promotion has skyrocketed in recent years. Therefore, it is very interesting to examine this extension of the marketing life cycle within farms (Marquardt et al., 2011) and (Bittner and Müller, 2011).

\section{Social media}

People have been socializing for millenia, but thanks to the Internet, the possibility of establishing contacts online in virtual places has arisen. Overthelastfewyears, various socialnetworks have been developed on different platforms such as Twitter, YouTube, Facebook, Linkedln and many more. Over time, these began to become an integral part of everyday life. Thanks to the possibility of creating connections with other people, these media allow us new social opportunities, which may include making new contacts, expressing feelings, normal communication, creating one's own career and sharing interesting things from life (Eger, 2015). According to Safko and Brake (2009), social media are all web networks that mediate online communication between their users, and this communication includes the sharing of opinions, information and knowledge. Griner (2009) has a similar approach to social networks, describing them as a digital tool for building an online network across users and sharing information between them. Whereas, according to Boyd (2007), social networks are defined as: "A web service that allows individuals to create a public or at least partially public profile within a defined and limited higher system. A social network is formed by a set of subusers who share a common interest. "According to this definition, various types of profiles are created on social networks, which are needed for communication between users. Kaplan (2010) defines social media a little differently. According to him, social media is a group of Internet applications that enable the creation, sharing and modification of user content, which are created in technology based on Web 2.0. Where Web 2.0 is an environment that allows each other to communicate and create and share content between users in a virtual world. Harris (2009) explains how social media works, and thus defined five basic functions for their use: to $\log$ in, rate, view, comment, and create. Currently, there is a wide field of social media, which differ according to the focus of networks and functions. According to Kozel (2011), social media can be divided as follows:

- social networks (Facebook, Myspace, Linkedln),

- blogs, videoblogs, microblogs (Twitter),

- discussion forums, Q\&A portals (Yahoo! answers),

- $\quad$ wikis (Wikipedia, Google Knol),

- $\quad$ social education systems (Digg, delicious, Jagg, Reddit),

- $\quad$ shared multimedia (YouTube, Flickr),

- virtual environments (Second Life, The Sims).

Social networks are becoming an indispensable part of the functioning of individuals, companies and modern society as a whole. Today, a total of 3.4 billion users use social networks, which is almost half of the world's population. Social networks have been around for many years, but the first major milestone was the founding of Facebook in 2004. Social networks have undergone tremendous development in those 16 years. Hundreds of projects have emerged that have sought to gain market share and innovate in digital communications and user interaction. The number of users on the Internet has doubled since 2010, and another one billion new users are expected to join next year. And most of them join social networks. The further development of social networks is therefore almost guaranteed in the coming years. (Nets in a handful, 2020)

Providing a suitable broadband communication infrastructure is the basis for the use of all modern Internet technologies and applications, including social media. Social media is evolving very fast and makes extensive use of multimedia content, which is closely related to the requirements for high quality connections. Rural areas generally face significant connectivity problems (including connection availability), especially connection quality. These problems have been monitored and analyzed by the Department of Information Technology for a long time and are addressed, for example, in the following papers: (Jarolímek and Vaněk, 2003) and (Vaněk et al., 2008) and (Šimek et al., 2014).

\section{Social media users}

It can be stated that social media is an artificial platform of "general knowledge", where 
an event or product can be highly valued. (Cardoso and Espinosa, 2020).

Facebook (the most widespread social network in the Czech Republic) began to be an effective tool when it exceeded the so-called critical limit. This limit represents at least a $15 \%$ share of the social networking market. Registered users have exceeded the critical limit, and user numbers have not stopped growing, resulting in higher popularity. Figure 1 clearly shows that Facebook is still the number one network in the Czech Republic, followed by YouTube and Instagram. (H1, 2020)

Facebook users are influenced by their lifestyle and similarly by their friends. As well as sites that are very popular among target groups, social networks integrate the presentations of many companies including those which focus on agriculture and agricultural products. (Satin-Hernandez and Robinson, 2015).

Trends on social networks in the Czech Republic provide an overview of daily usage across social networks in the Czech Republic for the 15-25 age group. In the autumn of 2019, the daily usage of this target group on Facebook was $72 \%$. This is twelve percentage points less than in the same period in 2018, but Facebook is still the most effective in this respect. $(\mathrm{H} 1,2020)$

At the same time, however, there is a noticeable increase in usage on Instagram and that of YouTube. The values for these two platforms follow a growing trend. In 2020, the share of daily usage on Instagram can be expected to grow, to the detriment of Facebook. Despite this fact, it is still true that the young group is still best reached by advertisers on Facebook. See Figure 1.

Facebook is often referred to in marketing agencies as a social network that is slowly declining. However, the statistics do not correspond to this, see Figure 2. Czechs spend 64 minutes a day on Facebook, and 62 minutes on Youtube. This chart

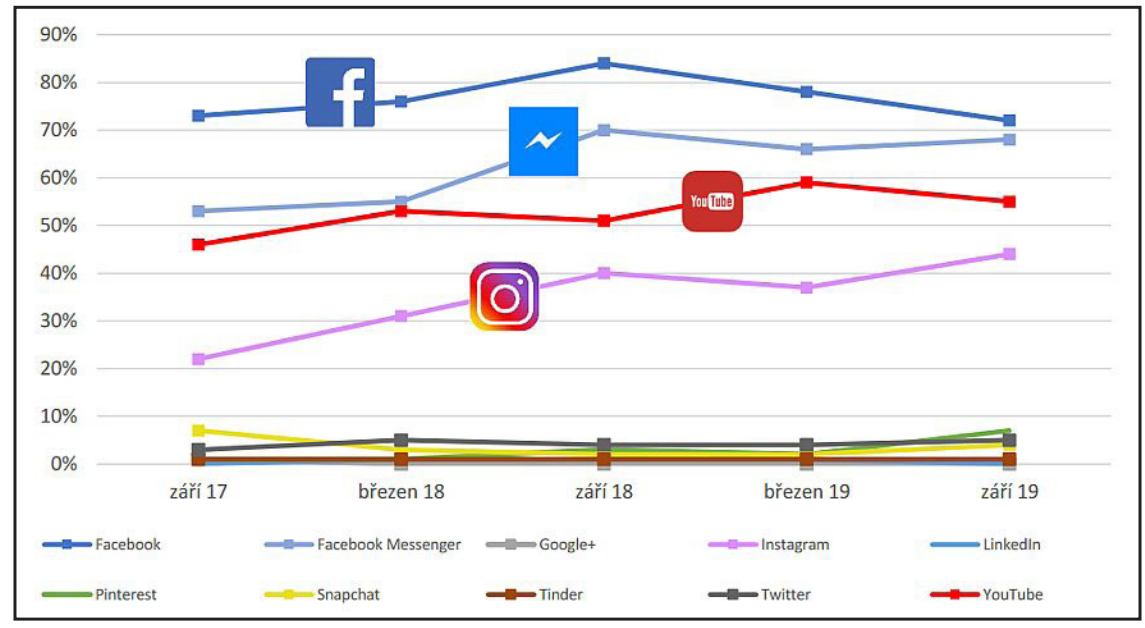

Source: H1.cz

Figure 1: Social network trends in 2020.

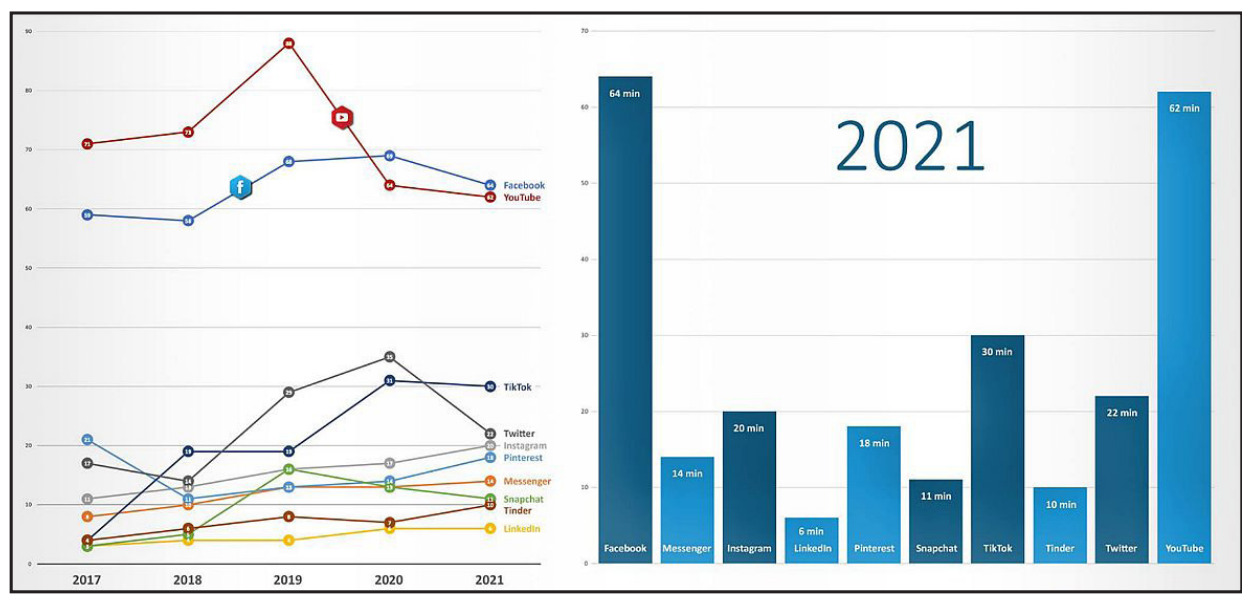

Source: H1.cz

Figure 2: How much time do users from Czech Republic spend on social networks (minutes). 
demonstrates the tremendous power of Facebook, and any advertising investment on Facebook will pay off quickly in the form of user awareness of the product or brand.

Facebook had over 2.6 billion active monthly users, as of Q1, 2020. This makes it the biggest social networking site in the world. Also, the number of users almost doubled in the last five years, clearly indicating that it is still popular and relevant, see Figure 3.

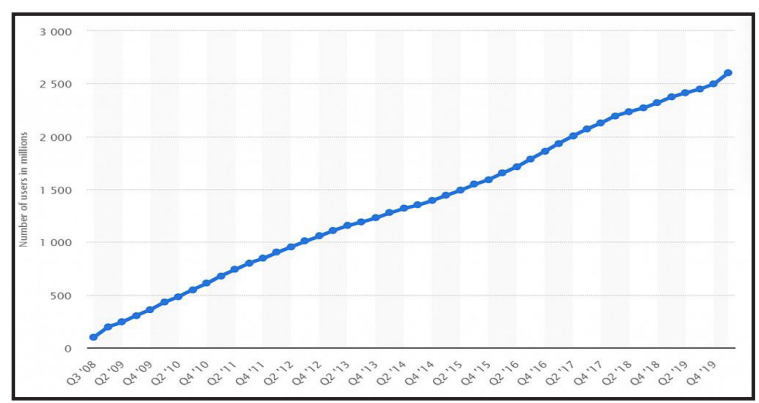

Source: Statista.com

Figure 3: Facebook users per day.

\section{Materials and methods}

In the spring of 2021, an online questionnaire survey was conducted on the development of information and communication technologies (ICT) in agricultural production enterprises, which covered the entire territory of the Czech Republic. For the first time, the paper form of the questionnaire was dropped entirely. The survey mainly addressed companies that manage at least 100 ha of arable land. The aim was to focus on agricultural enterprises from a comprehensive perspective on the development of ICT, which can be observed especially within larger enterprises. More than 700 questionnaires were collected. The survey focused on the current state and development of ICT, including related issues such as internet connection, internet use, mobile communications, the use of IoT and social media, and last but not least the impact of the COVID-19 pandemic in this area. In general, the use of social media, the acquisition of information for business activities and the impact of coronavirus measures on the operation of the company were analyzed.

\section{Results and discussion}

The survey shows that the target group actively uses social networks. Business and marketing were cited as reasons for using the social networks. The types of social networks used according to the answers drawn from Survey 2021 are shown in Figure 4.

\section{Using the social networks for business and marketing.}

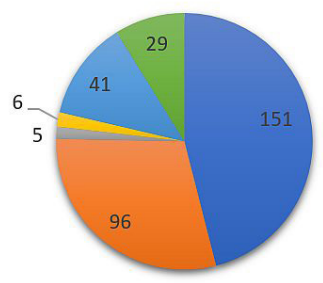

घacebook घoogle+ $\square$ Linkedln $\square$ Twitter घJiné $\square$ Instagram

Note: This question was answered by 239 respondents. In the „other" answer, respondents most commonly replied that they are using social networks but did not want to specify which ones or for what purpose.

Source: Own processing.

Figure 4: Using the social networks for business and marketing.

Figure 5 illustrates, which companies use social networks for business activities. The most active are those enterprises that farm on 50 - 500 ha of arable land. This confirms that the digital divide in these companies is being reduced by the usage of social networks. Companies use them to their advantage with regards to the promotion and establishment of new contacts with customers or suppliers.

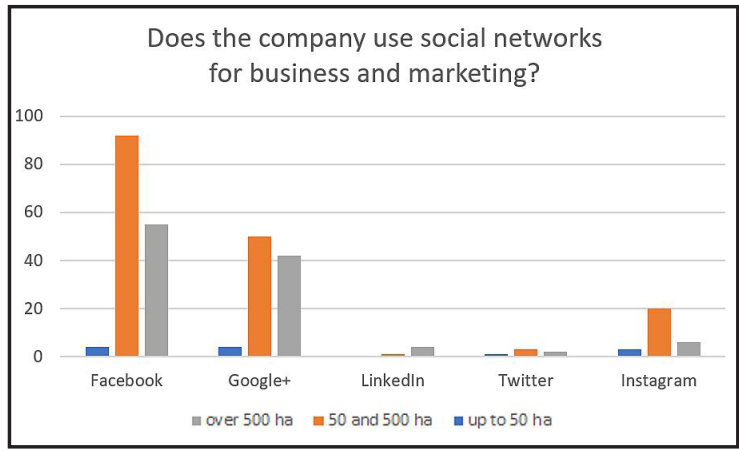

Source: Own processing.

Figure 5: Does the company use social networks for business and marketing? (separated by area of arable land).

A categorization into three groups of enterprises based on area of arable land was chosen for a certain broader view of the given issue: up to 50 ha, 50 - 500 ha and over 500 ha, which also corresponds to the UTIPA methodology (User-Technological Index of Precision Agriculture) (Jarolímek et al., 2017).

Figure 6 shows the development of the use of social networks in agricultural enterprises in 2011, 2014, 2016 and 2021. The graph shows a significant 
decline in Facebook in 2014 and 2016. A possible explanation is that new networks have appeared on the market. (Tinder, TikTok), which were discovered and used for a shorter period of time. Furthermore, in the years of decline, Facebook was more of a social network for the 20-30 age group. Now, after about 8 years, users are older and are still connected to groups that benefit them in the form of knowledge about new products, etc. In 2020, the use of Facebook skyrocketed again. The explanation for this increase in the use of Facebook is the pandemic situation in the Czech Republic and in the world. As mentioned in the Introduction chapter, Facebook seemed to be a lesser-used medium at one point, but it can be assumed that the coronavirus pandemic situation has returned Facebook to the forefront and businesses have begun to present themselves via Facebook to reach a new part of their target audience.

In general, this has led to a shift towards social networks that are well-known and established themselves over longer time period. This was a way to connect with the world of friends, business, new contacts and information about new products. The first usage of Instagram social network by agricultural companies has been a recorded in 2016. Overall, the graph suggests that the use of social networks is still in the growth phase.

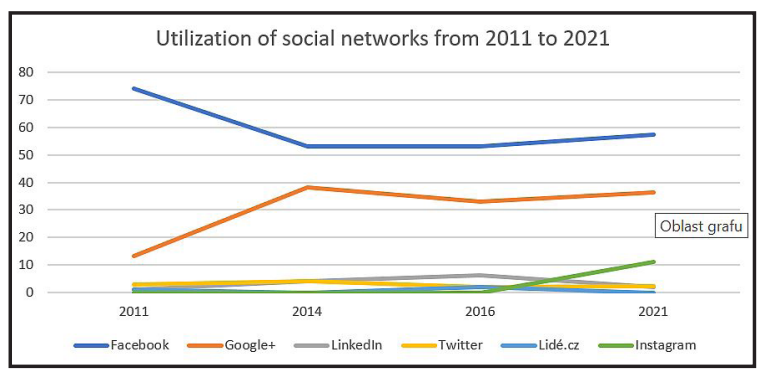

Source: own processing

Figure 6: Utilization of social networks from 2011 to 2021 in rural areas.

Social networks are used primarily for company public presentation, secondly for corporate communication and, last but not least, as a source of information.

With the development of the information society and the continuing adoption of ICT, attention is also shifting towards electronic information sources in the agricultural and rural environment. This trend will continue on an ongoing basis. The problem of the so-called "digital divide" is gradually being overcome.
It can be seen from Figure 8 that most information is obtained by agricultural holdings from the Internet. This is followed by the professional press and the experience of colleagues (best practices). Social networks are a source of information with respect to suppliers, organizations or colleagues. Large players in the agricultural machinery market have been reducing investments in paper leaflets for a long time and are betting on Facebook and Instagram - thus on the good experiences of other colleagues and immediate acquisition of news before the season directly from the source or through industry portals.

From the results of the survey shown in Figure 7, the general hypothesis of increasing usage of the Internet as a basic source of information was confirmed. The Internet is regularly used by companies with a demonstrable dependence on the size of the company, see Figure 8 (the largest ones use it the most regularly, etc.). If the Internet is not used as a source of information on a regular basis, it is used at least occasionally - the number of companies that do not use internet at all is negligible.

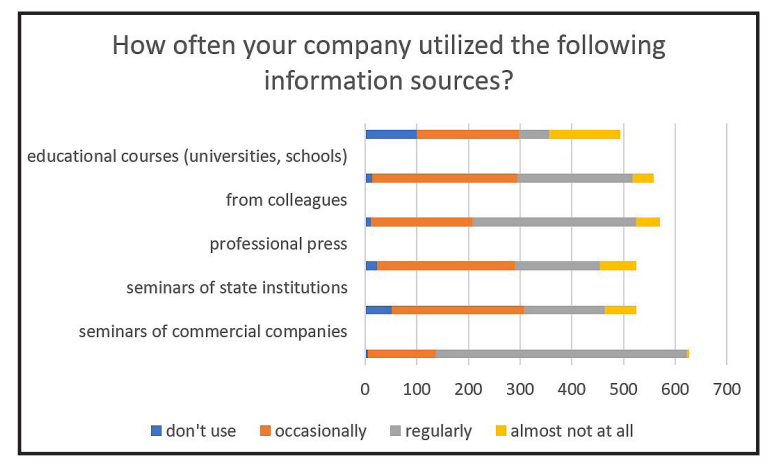

Source: own processing

Figure 7: How often your company utilized the following information sources?

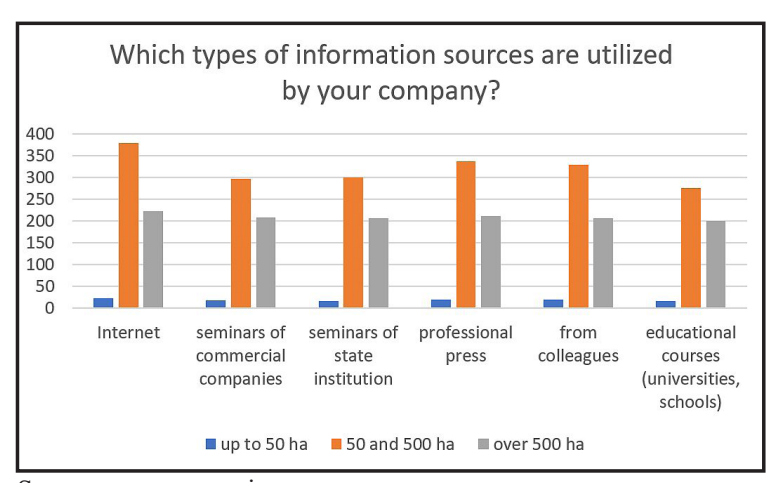

Source: own processing

Figure 8: Information sources utilized by agricultural companies (separated by area of arable land) 
Impact of the coronavirus pandemic on the use of ICT in agriculture (in rural areas)

Social networks in rural areas make a significant contribution to reducing the digital divide. Users of social networks can access the necessary information, not only within more types of networks, but also more interest groups. In general, farm employees can be considered conservative in using new technologies to improve and simplify their own work, as well as in promoting and establishing new contacts that could direct employees closer to modern technologies and use them to their advantage (more customers, promotion of your own brand, etc.).

The questionnaire survey also examined which statements the individual companies identify with regard to the COVID-19 measures. The results show that the coronavirus pandemic has affected the functioning of companies only partially or not at all. In summary, COVID-19 most influenced communication with customers and suppliers, which began to be more organized using online tools, see Figure 9.

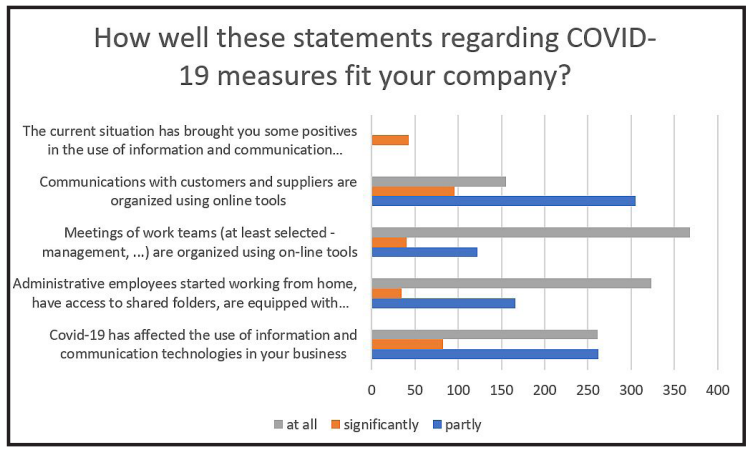

Source: Own processing

Figure 9: How well these statements regarding COVID-19 measures fit your company?

Figure 10 confirms that farms with more than 50 ha of arable land have been able to respond more quickly and flexibly to changes resulting from the coronavirus pandemic.

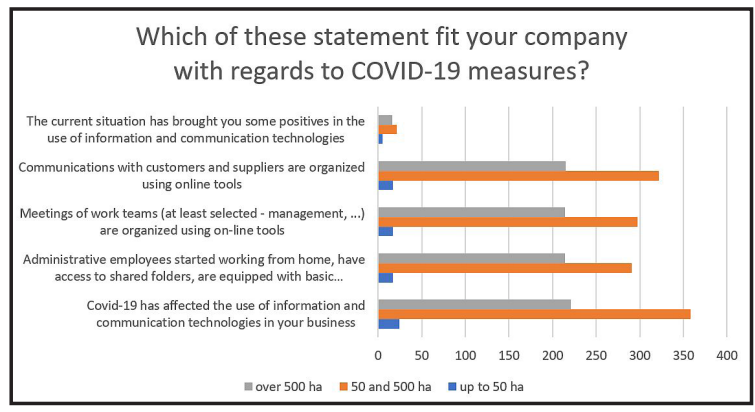

Source: Own processing

Figure 10: Which of these statement fit your company with regards to COVID-19 measures? (separated by area of arable land).

\section{Conclusion}

In rural areas, it is the people themselves who start and promote digitization projects and work with professional actors from outside. These innovators see digitization as a chance to solve rural problems, such as limited mobility, declining community interactions, demographic change or the digital divide between urban and rural areas. (Zerrer and Sept, 2020)

According to Albar and Houque (2019), the adoption of information and communication technologies (ICT) will enable local SMEs to participate in the European market. Relative benefits, top management support, culture, regulatory environment, capability for Innovation by the owner / manager and ICT knowledge have a significant impact on the overall adoption of ICT in SMEs, while compatibility, complexity and competitive environment have no significant relationship to ICT adoption.

The Department of Information Technology has experience from its own practice that most suppliers and processors limit investments in paper leaflets, etc., but purposefully use social networks and contacts of selected groups on social networks for their promotion or recruitment of new employees.

The further development of social media marketing offers a number of interesting questions for further publishable outputs and subsequent research in the coming years, as the development of social networks is closely linked to the development of customer acquisition strategies.

The authors of the paper will continue to monitor the development of social networks in this specific domain and expect a steady upward trend in the use of social media in agricultural enterprises for both agricultural and mainly non-agricultural activities.

\section{Acknowledgements}

The results and knowledge included herein have been obtained owing to support from the following institutional grant. Internal grant agency of the Faculty of Economics and Management, Czech University of Life Sciences Prague, grant no. 2021A0019. 
Corresponding authors

Ing. Eva Kánská

Department of Information Technology, Faculty of Economics and Management

Czech University of Life Sciences Prague, Kamýcká 129, 16500 Prague, Czech Republic

E-mail:kanska@pef.czu.cz

\section{References}

[1] Albar, A. M. and Hoque, M. R. (2019) "Factors affecting the adoption of information and communication technology in small and medium enterprises: a perspective from rural Saudi Arabia", Information Technology for Development, Vol. 25, No. 4, pp. 715-738. E-ISSN 1554-0170, ISSN 0268-1102. DOI 10.1080/02681102.2017.1390437.

[2] Bittner, S. and Müller, A. (2011) "Social networking tools and research information systems: Do they compete?", Webology. [On-line]. Available: http://www.webology.org/2011/v8n1/a82.html. [Accessed: 8 Aug. 2021].

[3] Boyd, D. and Ellison, N. B. (2007) "Social Network Sites: Definition, History, and Scholarship". Journal of Computer-Mediated Communication, Vol. 13, No.1, pp. 210-230. ISSN 1083-6101. DOI 10.1111/j.1083-6101.2007.00393.x.

[4] Cardoso Castro, P.P . and Espinosa, A. (2020) "Identification of organisational pathologies: *Exploration of social network analysis to support the viable system model diagnostic", Kybernetes, Vol. 49, No. 2, pp. 285-312. ISSN 0368-492X. DOI 10.1108/K-10-2018-0557.

[5] Eger, L., Petrtyl, J., Kunešová, H., Mičík, M. and Peška, M. (2015) "Marketing na internetu", WestBoheiman University Plzeň. ISBN 978-80-261-0573- 2 (in Czech).

[6] Griner, M. (2009) "Everything you need to know about social media". [On-line]. Available: http://slideshare.net/griner/everything-you-needto-know-about-socialmedia-1937744. [Accessed: 23 July 2021].

[7] H1 (2020) "Sociální sítě v Česku v roce 2019" [On-line]. Available: https://www.h1.cz/upload/680social-trendy-2020-groupm.pdf . [Accessed: 23 July 2021]. (in Czech).

[8] Harris, L. and Rae, A. (2009) "Social networks: the future of marketing for small business", Journal of Business Strategy, Vol. 30, No. 5, pp. 24-31. ISSN 0275-6668. DOI 10.1108/02756660910987581.

[9] IMH, Influence Marketing Hub (2021) "28 Facebook Statistics - Revenue, Users (+ Everything You Need to Know in (2021)". [On-line]. Available: https://influencermarketinghub.com/facebookstatistics/. [Accessed: 2 June 2021]. (in Czech).

[10] Jarolímek, J. and Vaněk, J. (2003) "The intensity and quality of Internet usage in the agriculture sector and possibilities of its further development", Plant, Soil and Environment, Vol. 11, pp. 525-529. ISSN 1214-1178. DOI 10.17221/4188-PSE.

[11] Kánská, E., Jarolímek, J., Hlavsa T., Šimek, P., Vaněk, J. and Vogeltanzová, T. (2012) "Using social networks as an integration tool in rural areas of the Czech Republic - agricultural enterprises", Acta Universitatis Agriculturae et Silviculturae Mendelianae Brunensis, Vol. 60, No. 4, pp. 173-180. ISSN 2464-8310. DOI 10.11118/actaun201260040173.

[12] Kaplan, A. and Haenlin, M. (2010) "Users of the world, unite! The challenges and opportunities of Social Media", Business Horizons, Vol. 53, No. 1, pp. 59-68. ISSN 0007-6813. DOI 10.1016/j.bushor.2009.09.003.

[13] Kozel, R., Mynářová, L. and Svobodová, H. (2011) "Moderní metody a techniky marketingového výzkumu", Prague: Grada. ISBN 978-80-247-3527-6. (in Czech).

[14] Marquardt, D., Möllers, J. and Buchenrieder, G. (2011) "Why Do We Need Networking for European Rural Development Policies?", Eurochoices, Vol. 10, No. 2, pp. 22-29. ISSN 14780917. DOI 10.1111/j.1746-692X.2011.00196.x.

[15] Safko, L. and Brake, D. K. (2009) "The social media bible: tactics, tools, and strategies for business success", Hoboken, N.J.. John Wiley. ISBN 978-0- 470-41155-1. 
[16] Satin-Hernandez, E. and Robinson, L. (2015) "A Community Engagement Case Study of the Somerville Mobile Farmers' Market", Journal of Agriculture, Food Systems, and Community Development, Vol. 5, No. 4, pp. 95-98. E-ISSN 2152-0801. DOI 10.5304/jafscd.2015.054.015.

[17] Sítě v hrsti (2020) "Kolik uživateli použivá sociální sítě v roce 2020?" Oct. 2020. [On-line]. Available: https://sitevhrsti.cz/velikost-socialnich-siti-2020/. [Accessed: 23 July 2021]. (in Czech).

[18] Šimek, P., Stočes, M. and Vaněk, J. (2014) "Mobile Access to Information in the Agrarian Sector", AGRIS on-line Papers in Economics and Informatics, Vol. 6, No. 2, pp. 89-96. ISSN 1804 1930. DOI 10.22004/ag.econ.182494.

[19] Vaněk, J., Jarolímek, J. and Šimek, P. (2008) "Development of communication infrastructure in rural areas of the Czech Republic", Agricultural Economics, Vol. 54, No. 3, pp. 129-134. ISSN 0139-570X.

[20] Zerrer, N. and Sept, A. (2020) "Smart Villagers as Actors of Digital Social Innovation in Rural Areas", Urban Planning, Vol. 5, No. 4, pp. 78-88. ISSN 2183-7635. DOI 10.17645/up.v5i4.3183.

[21] Jarolímek, J., Stočes, M., Masner, J., Vaněk, J., Šimek, P., Pavlík, J. and Rajtr, J. (2017) "UserTechnological Index of Precision Agriculture", Agris on-line Papers in Economics and Informatics, Vol. 9, No. 1, pp. 69-75. ISSN 1804-1930. DOI 10.7160/aol.2017.090106. 